Central Washington University

ScholarWorks@CWU

All Faculty Scholarship for the College of the Sciences

College of the Sciences

$10-1-2020$

\title{
Hot but Not Dry: Modest Changes in Water Relations for an Epiphytic Bromeliad in a Tropical Dry Deciduous Forest
}

\author{
Saúl Hernández-Robinson \\ Centro de Investigación Científica de Yucatán \\ Eric A. Graham \\ Central Washington University, eric.graham@cwu.edu \\ Olivia Hernández-González \\ Universidad Intercultural Maya de Quintana Roo \\ Roberth Us-Santamaría \\ Centro de Investigación Científica de Yucatán \\ José Luis Simá \\ Centro de Investigación Científica de Yucatán
}

See next page for additional authors

Follow this and additional works at: https://digitalcommons.cwu.edu/cotsfac

Part of the Environmental Health and Protection Commons, Environmental Indicators and Impact Assessment Commons, Forest Biology Commons, and the Plant Biology Commons

\section{Recommended Citation}

Hernández-Robinson, S., Graham, E. A., Hernández-González, O., Us-Santamaría, R., Simá, J. L., ArellanoMartín, F., \& Andrade, J. L. (2020). Hot but Not Dry: Modest Changes in Water Relations for an Epiphytic Bromeliad in a Tropical Dry Deciduous Forest. International Journal of Plant Sciences, 181(9), 945-954. https://doi.org/10.1086/710487

This Article is brought to you for free and open access by the College of the Sciences at ScholarWorks@CWU. It has been accepted for inclusion in All Faculty Scholarship for the College of the Sciences by an authorized administrator of ScholarWorks@CWU. For more information, please contact scholarworks@cwu.edu. 


\section{Authors}

Saúl Hernández-Robinson, Eric A. Graham, Olivia Hernández-González, Roberth Us-Santamaría, José Luis Simá, Fernando Arellano-Martín, and José Luis Andrade 


\title{
HOT BUT NOT DRY: MODEST CHANGES IN WATER RELATIONS FOR AN EPIPHYTIC BROMELIAD IN A TROPICAL DRY DECIDUOUS FOREST
}

\author{
Saúl Hernández-Robinson, ${ }^{1, *}$ Eric A. Graham, ${ }^{2}{ }^{\dagger}$ Olivia Hernández-González, ${ }^{3}{ }^{\prime} \neq$ Roberth Us-Santamaría, ${ }^{4, *}$ \\ José Luis Simá, ${ }^{5, *}$ Fernando Arellano-Martín, ${ }^{6, \S}$ and José Luis Andrade ${ }^{7, *}$ \\ *Unidad de Recursos Naturales, Centro de Investigación Científica de Yucatán, A.C., Calle 43 Número 130, Colonia Chuburná de Hidalgo, Mérida, \\ 97205, Yucatán, México; +Department of Biology, Central Washington University, 400 East University Way, Ellensburg, Washington 98926, USA; \\ fUniversidad Intercultural Maya de Quintana Roo, Carretera Muna-Felipe Carrillo Puerto Km. 137, S/N Presumida, Municipio de José María \\ Morelos, C.P. 77870, Quintana Roo, México; and §Instituto Nacional de Investigaciones Forestales, Agrícolas y Pecuarias, \\ Campo Experimental Chetumal, Km. 25 Carretera Chetumal, Bacalar, C.P. 77000, Xul-Ha, Quintana Roo, México
}

Editor: Barry A. Logan

Premise of research. Epiphytic bromeliads endure intense seasonal environmental changes in the canopy of dry tropical deciduous forests. The analysis of the physiological responses of these epiphytes to environmental changes can be useful in assessing their plasticity, vulnerability, and adaptations to such extreme habitats.

Methodology. We measured microenvironmental variables and water relations for plants of the epiphytic bromeliad Tillandsia brachycaulos in three microhabitats within the canopy of a dry tropical forest. We measured individual plants for seasonal and spatial differences in light, leaf temperature, osmotic potential, cell wall elasticity, and relative capacitance as indications of their physiological responses to the changing environment.

Pivotal results. We detected greater physiological differences for leaves of T. brachycaulos among seasons than among microhabitats. Osmotic potential decreased in the early dry season, especially in the low and middle strata within the canopy, and leaf relative capacitance increased.

Conclusions. Individuals of T. brachycaulos displayed modest leaf physiological responses to the strong seasonal environmental changes within the canopy of this tropical forest. Such responses are in agreement with the observation that when water is available, it has high water potential, and thus water storage is the main strategy for surviving in such extreme conditions.

Keywords: leaf temperature, osmotic potential, relative capacitance, Tillandsia brachycaulos, Yucatán.

\section{Introduction}

Vertical stratification of epiphytes is well documented in tropical forests (Rascher et al. 2012; Wagner et al. 2013; Petter et al. 2016). In tropical dry deciduous forests, seasonal rainfall and deciduousness can dramatically change the environmental conditions for epiphytes. For example, incident photosynthetic photon flux (PPF; $\mu \mathrm{mol} \mathrm{m}^{-2} \mathrm{~s}^{-1}$ ) for some epiphytes is about nine times higher during the dry season than during the wet season (Graham and Andrade 2004; Cervantes et al. 2005). Moreover, during the warmest times of the day, the leaf temperatures of plants in lower sites within the canopy are significantly higher

1 Email: robinson_saul@hotmail.com.

2 Email: eric.graham@cwu.edu.

3 Email: olivia.hernandez@uimqroo.edu.mx.

4 Email: roberthus@cicy.mx.

5 Email: 1simag@cicy.mx.

6 Email: ferarellanom@gmail.com.

Author for correspondence; email: andrade@cicy.mx.

Manuscript received March 2019; revised manuscript received December 2019; electronically published October 1, 2020. than the temperature of the air, which can affect growth and reproduction (Cervantes et al. 2005). To cope with these strong seasonal changes in microenvironment, epiphytes possess several adaptations, such as succulence, water-impounding shoots, specialized roots, crassulacean acid metabolism (CAM), and foliar trichomes (Benzing 1990; Zotz 2016). Indeed, epiphyte position in the canopy often depends on a combination of these characteristics and on the ability to acclimate to environmental changes (Maxwell et al. 1995; Andrade and Nobel 1997; Hietz and Briones 1998; Zotz and Andrade 1998; Griffiths and Maxwell 1999; Gonzalez-Salvatierra et al. 2010; Cach-Pérez et al. 2013; Chilpa-Galván et al. 2013; de la Rosa-Manzano et al. 2017).

In tropical dry deciduous forests, changes in water availability with season can be extreme. During the dry season, the decreased water availability for epiphytes is accompanied by an increase of PPF due to the deciduousness of the host trees, further enhancing desiccating conditions and increasing stress (Graham and Andrade 2004; Reyes-García et al. 2012; Crain and Tremblay 2017). This increase in light is usually accompanied by increases in temperature and vapor pressure deficit (VPD), which explains the prevalence of CAM species in tropical dry ecosystems (Griffiths and Smith 1983; Cervera et al. 
2006; Reyes-García et al. 2008; Ricalde et al. 2010; CachPérez et al. 2013).

Although succulence recovery is very rapid in epiphytes and occurs within a few hours or a few days after rewetting (Sinclair 1983; Andrade and Nobel 1997), neither water tissue recovery nor CAM can fully explain the occurrence of an epiphyte in a particular microsite within the canopy. For epiphytic orchids, leaf area, leaf size, leaf succulence, and pseudobulb size are important for survival in certain microsites in tropical dry forests (de la Rosa-Manzano et al. 2014a, 2014b). In other forests, different adaptive mechanisms as a response to drought (either escape or avoidance) may be predominant within specific microhabitats (Zhang et al. 2016). Interestingly, individuals in exposed positions in the canopy may have more access to dew or fog, reducing drought stress under such potentially more extreme conditions (Andrade 2003; Graham and Andrade 2004; Reyes-García et al. 2008; de la Rosa-Manzano et al. 2014a; Wu et al. 2018; Chávez-Sahagún et al. 2019). Exposure may also be associated with an increase in tissue relative capacitance compared with individuals in the shade (Andrade et al. 2009).

High tissue relative capacitance is the ability to maintain high water potentials when water content decreases, and it relates to succulence, the tissue volume-to-surface area ratio, osmotic adjustment, and the volumetric elastic modulus ( $\epsilon$; Nobel 2009; Jones 2013). Even though epiphytes tend to be drought tolerant, osmotic potentials $\left(\Psi_{\pi}\right)$ are unexpectedly high and are regularly less negative than $-1.0 \mathrm{MPa}$ (Sinclair 1983; Smith et al. 1986; Martin 1994; Zotz and Hietz 2001; Martin et al. 2004; de la Rosa-Manzano et al. 2014b). However, some epiphytic bromeliads decrease $\Psi_{\pi}$ to about $-1.5 \mathrm{MPa}$ during the dry season (Cach-Pérez et al. 2018).

Individuals of the epiphyte Tillandsia brachycaulos Schlechtendal (Bromeliaceae) are abundant in tropical dry deciduous forests of northern Yucatán, Mexico, and they occur nearly everywhere in the host trees, from very close to the forest floor to the upper canopy (Mondragón et al. 1999). A previous study indicated that those individuals inhabiting the lower canopy have reduced growth and reproduction rates, which are also correlated with high leaf temperatures (Cervantes et al. 2005). However, water relations studies for this species in different vertical microhabitats are lacking. We hypothesized that plants of $T$. brachycaulos would increase their foliar relative capacitance in the dry season, mainly through a decrease of $\Psi_{\pi}$. Those plants growing in the lower canopy were expected to enhance their relative capacitance more than individuals in the upper canopy, which would have more access to rain, fog, and dew, all water sources at high water potential (Andrade 2003; Graham and Andrade 2004; Reyes-García et al. 2012).

\section{Material and Methods}

\section{Study Site and Plant Species}

Field measurements were made in Dzibilchaltún National Park, a secondary tropical dry deciduous forest regenerating in a 539 -ha protected area (lat. $21^{\circ} 05^{\prime} \mathrm{N}$, long. $89^{\circ} 35^{\prime} \mathrm{W} ; 10 \mathrm{~m}$ in elevation) in the Yucatán Peninsula, Mexico. Trees in the family Fabaceae dominate the forest. It receives $650-700 \mathrm{~mm}$ in annual rainfall and has a mean air temperature of $26^{\circ} \mathrm{C}$, a maximum of $45^{\circ} \mathrm{C}$, and a minimum of $10^{\circ} \mathrm{C}$ (Thien et al. 1982). Most trees are leafless during the dry season, which occurs from March to May. Between the wet and dry seasons there is an early dry season, locally known as "nortes" (from November to February), characterized by 2 - to 3 -d events of strong winds $\left(>80 \mathrm{~km} \mathrm{~h}^{-1}\right)$, little rainfall $(20-60 \mathrm{~mm})$, and relatively low temperatures $\left(<20^{\circ} \mathrm{C}\right.$; Orellana 1999$)$.

Tillandsia brachycaulos is one of the most abundant and widespread epiphytic bromeliads in the Yucatán Peninsula (Cach-Pérez et al. 2013). It is considered an atmospheric epiphyte (ecophysiological type V, according to Benzing [2000]), although it has some water impoundment capacity (Andrade 2003). Individuals of T. brachycaulos located in five neighboring trees of three species (Gymnopodium floribundum Rolfe, three individuals; Pithecellobium dulce (Roxb.) Benth; and Randia obcordata S. Watson) were selected for microenvironmental and physiological measurements. All tree species in the study site are of short stature (average height, $4.1 \pm 0.3 \mathrm{~m}$; Graham and Andrade 2004). Following previous studies (Cervantes et al. 2005; Chilpa-Galván et al. 2013), all measurements were performed on individuals from three canopy strata: from 0.30 to $0.40 \mathrm{~m}$ in height (low stratum), from 1.40 to $1.50 \mathrm{~m}$ in height (middle stratum), and from 2.50 to $2.60 \mathrm{~m}$ in height (high stratum). All adult plants in each stratum were labeled and mapped for random sampling.

\section{Environmental Measurements}

Because each season in the region is relatively well defined (Orellana 1999; Orellana et al. 2009), we chose to measure environmental variables for only three to five consecutive days within each season. PPF was measured at about $20 \mathrm{~mm}$ above randomly selected epiphytes ( $n=5$ per stratum) using galliumarsenide-phosphide photodiodes (Hamamatsu, Middlesex, NJ) calibrated against an LI-190SB quantum sensor (LI-COR, Lincoln, NV). As a reference for PPF above the canopy, two additional sensors were placed at approximately $15 \mathrm{~m}$ above the ground in a clearing. Leaf temperatures were measured on the abaxial surface of one leaf per plant from midrosette using 0.08-mm-diameter copper-constantan thermocouples attached with porous adhesive tape. Air temperature and humidity were measured with a Vaisala shielded probe (HMP35C-L, Campbell Scientific, Logan, UT). All sensors were sampled at 15-s intervals, and average values were recorded every 10 min with a datalogger (CR21X, Campbell Scientific) equipped with a 16channel multiplexer (AM416, Campbell Scientific).

\section{Tissue Water Relations Measurements}

Whole midrosette leaves of randomly selected individuals from each stratum were collected at 0700, 1300, and 1600 hours during $1 \mathrm{~d}$ in each season (first Monday of January, May, and August 2013; $n=3-5$ per stratum); samples for $\Psi_{\pi}$ were stored in liquid nitrogen and transported to the laboratory (within a 15-min drive). After thawing, leaf samples were crushed with a vice, and a filter-paper disk was saturated with the expressed cell sap. The saturated paper disk was then placed in a vapor pressure 5520 osmometer (Wescor, Logan, UT) to determine 
Table 1

Daily Integrals of Photosynthetic Photon Flux (PPF), Maximum PPF, and Maximum Vapor Pressure Deficit (VPD) above the Canopy in Three Seasons in the Tropical Dry Deciduous Forest in Dzibilchaltún National Park

\begin{tabular}{lccc}
\hline Season & Daily PPF $\left(\mathrm{mol} \mathrm{m}^{-2} \mathrm{~d}^{-1}\right)$ & Maximum PPF $\left(\mu \mathrm{mol} \mathrm{m}^{-2} \mathrm{~d}^{-1}\right)$ & Maximum VPD $(\mathrm{kPa})$ \\
\hline Early dry & $40.9 \pm 1.4$ & $1928 \pm 133$ & $3.92 \pm .32$ \\
Dry & $46.4 \pm 2.5$ & $2400 \pm 116$ & $4.79 \pm .76$ \\
Wet & $39.5 \pm 3.6$ & $2060 \pm 140$ & $1.89 \pm 1.63$ \\
\hline
\end{tabular}

Note. $\quad$ Data are means \pm standard errors $(n=5)$.

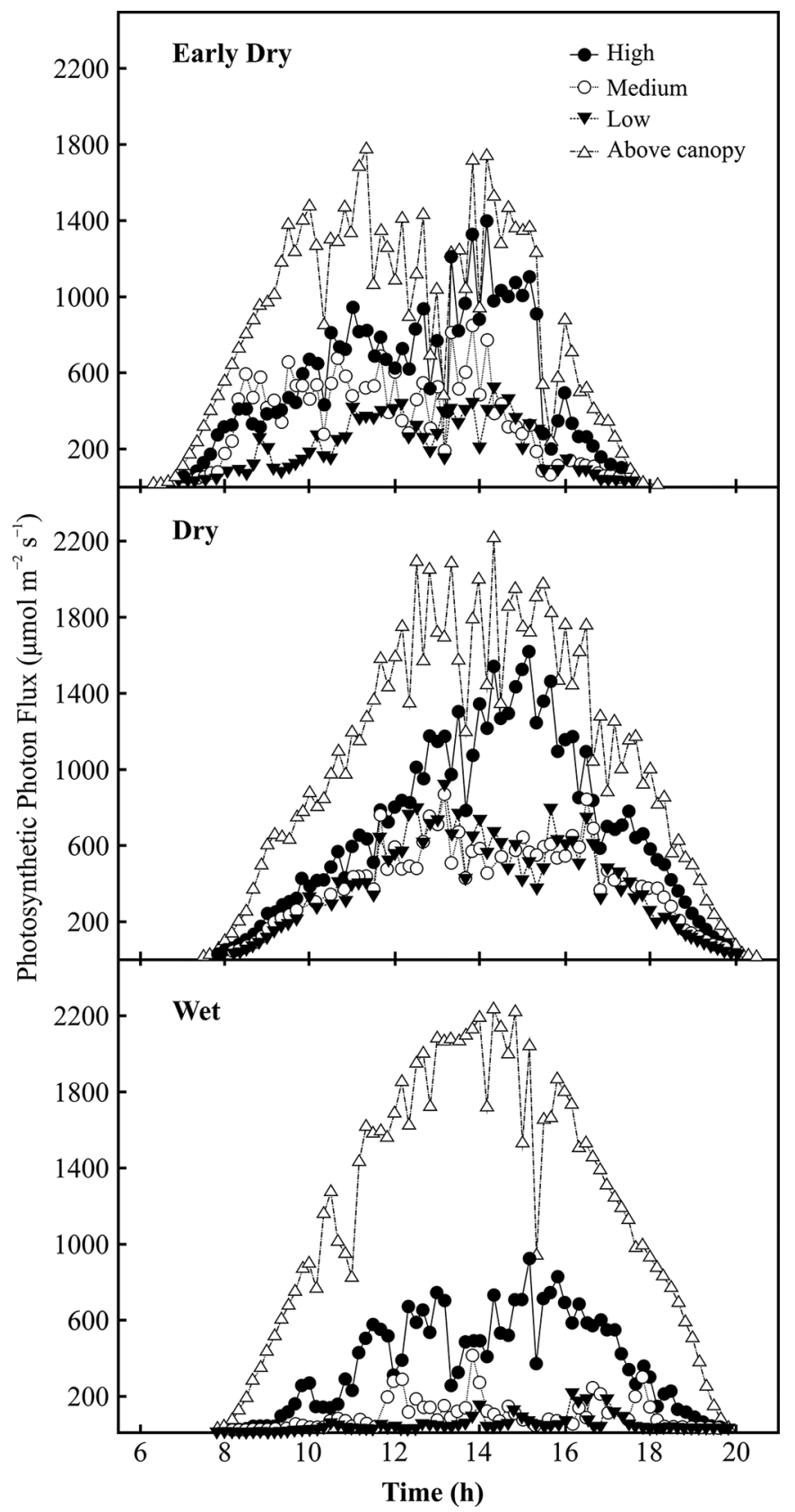

Fig. 1 Representative daily course of photosynthetic photon flux (PPF) above individuals of Tillandsia brachycaulos $(n=4)$ from different canopy strata (high strata represented by filled circles; medium represented by open circles; low represented by filled triangles) in the dry deciduous tropical forest of Dzibilchaltún National Park. PPF above the canopy (open triangles) is also shown. Measurements were taken on clear days during the early dry, dry, and wet seasons. 
Table 2

Daily Integrals of Photosynthetic Photon Flux (PPF) above Individuals of Tillandsia brachycaulos at Three Strata within the Canopy and in Three Seasons in the Tropical Dry Deciduous Forest in Dzibilchaltún National Park

\begin{tabular}{lccc}
\hline Stratum & Early dry season daily PPF $\left(\mathrm{mol} \mathrm{m}^{-2} \mathrm{~d}^{-1}\right)$ & Dry season daily PPF $\left(\mathrm{mol} \mathrm{m}^{-2} \mathrm{~d}^{-1}\right)$ & Wet season daily PPF $\left(\mathrm{mol} \mathrm{m}^{-2} \mathrm{~d}^{-1}\right)$ \\
\hline Low & $8.04 \pm 1.41$ & $17.39 \pm 1.63$ & $2.17 \pm .32$ \\
Middle & $13.58 \pm 1.52$ & $17.28 \pm 2.06$ & $3.37 \pm .76$ \\
High & $21.95 \pm 3.69$ & $31.43 \pm 5.54$ & $15.43 \pm 6.63$ \\
\hline
\end{tabular}

Note. Data are means \pm standard errors $(n=5)$.

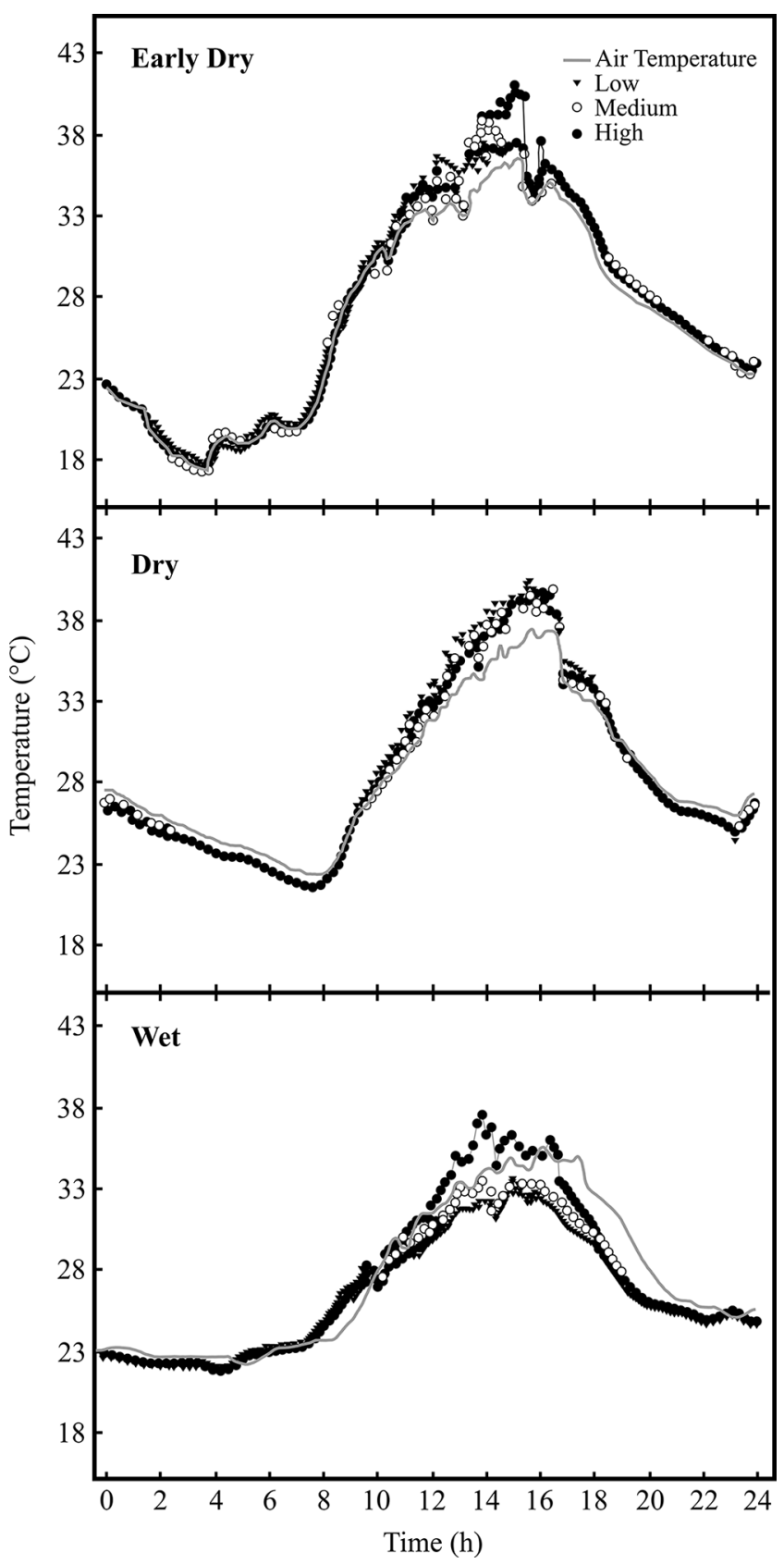

Fig. 2 Representative daily course of air temperatures (line) and leaf temperatures (symbols) of Tillandsia brachycaulos $(n=4)$ from different canopy strata (high strata represented by filled circles; medium represented by open circles; low represented by filled triangles) in the dry deciduous tropical forest of Dzibilchaltún National Park. Measurements were taken on clear days during the early dry, dry, and wet seasons. 
osmolality (mmol/kg). Results were then converted to $\Psi_{\pi}(\mathrm{MPa})$ using the van't Hoff relation (Nobel 2009).

Relative water content (RWC), defined as (fresh mass - dry mass)/(turgid mass - dry mass), was obtained for circular tissue samples $\left(0.95 \mathrm{~cm}^{2}\right)$ from midrosette leaves. Turgid mass was obtained after the samples were hydrated for $6 \mathrm{~h}$ at $25^{\circ} \mathrm{C}$ in sealed plastic vials containing wet filter paper saturated with distilled water. Dry mass was obtained after the samples were dried at $60^{\circ} \mathrm{C}$ until no further weight change occurred (generally less than $24 \mathrm{~h}$ ).

Water potential $\left(\Psi_{\mathrm{w}}\right)$ isotherms for leaf tissues were obtained psychometrically (Andrade and Nobel 1997; Zotz and Andrade 1998; Andrade et al. 2009). Fresh leaf tissue samples (5 $\mathrm{mm}$ in diameter) were hydrated as described above to reach an RWC of 1.0. We then placed hydrated samples in a vapor pressure osmometer (Wescor) to measure osmolality using the autorepeat mode. We then calculated $\Psi_{\mathrm{w}}$ as we had $\Psi_{\pi}$ for the samples. Subsequent measurements of fresh mass and ${ }^{\pi} \Psi_{w}$ were performed repeatedly after samples were allowed to dry in the air for $5 \mathrm{~min}$ in ambient laboratory conditions. Dry mass was obtained as described above. The relative capacitance (change in RWC per unit change in $\Psi_{\mathrm{w}}$ ) of the leaf tissues for an RWC between 1.0 and 0.6 was obtained from the water potential isotherms (the slope of each linear regression; $n=3-$ 4 plants for each stratum). Previous studies indicate that the average RWC for $T$. brachycaulos does not decrease below 0.6 during the dry season (Cach-Pérez 2013). Similarly, $\epsilon$ of the leaf tissues was calculated from the water potential isotherms as the change in pressure potential $\left(\Psi_{\mathrm{p}}\right)$ for a unit change in RWC (Ogburn and Edwards 2012).

\section{Statistical Analysis}

ANOVA followed by Tukey's mean comparison tests was performed to evaluate differences in water relations. Threeway ANOVAs were done for the osmotic potential data; the factors were time of day, stratum, and season. In addition, osmotic data for plants in all locations within the canopy were evaluated against the season. A linear regression was applied to determine the relative capacitance. For relative capacitance and the volumetric elastic modulus, the factors were stratum and season. All statistical analyses were completed using the software Statistica 7.0 (StatSoft, Tulsa, OK).

\section{Results}

\section{Microenvironmental Conditions}

PPF and VPD above the canopy changed greatly during the year. During the early dry season, VPD increased relative to the wet season, and it reached the highest values during the dry season; maximum VPD values were $3.92 \mathrm{kPa}$ in the early dry season and $4.79 \mathrm{kPa}$ in the dry season (table 1). Maximum PPF above the canopy was the highest in the dry season $\left(2400 \pm 216 \mu \mathrm{mol} \mathrm{m}^{-2} \mathrm{~s}^{-1}\right.$; table 1$)$.

Incident PPF above Tillandsia brachycaulos plants within the canopy also changed greatly during the year (fig. 1). During the afternoon in the early dry and dry seasons, individuals of $T$. brachycaulos in the high stratum had an incident PPF similar to the PPF above the canopy, but in the wet season, when host trees were fully leafed, PPF was lower than it was above the canopy for most individuals (fig. 1). In the dry season after host trees had dropped most of their leaves, the average daily PPF above T. brachycaulos in the high stratum was $31.43 \pm$ $5.54 \mathrm{~mol} \mathrm{~m}^{-2} \mathrm{~d}^{-1}$, almost two times greater than the incident PPF of individuals in the lower stratum $(P<0.05$; table 2$)$. During the wet season, the average daily PPF above $T$. brachycaulos at the high stratum was $15.43 \pm 6.63 \mathrm{~mol} \mathrm{~m}^{-2} \mathrm{~d}^{-1}$, about seven times greater than that of individuals in the low stratum $(P<0.01$; table 2).

Temperature differences between the air and the leaves of T. brachycaulos during typical clear days had distinct seasonal differences (fig. 2). Leaf temperatures were higher than air temperatures during the daytime in the early dry and dry seasons, whereas in the wet season during the daytime, leaf temperatures of most individuals were lower than that of the air. At night, leaf temperatures were lower than the air temperature, mainly during the dry and wet seasons (fig. 2).

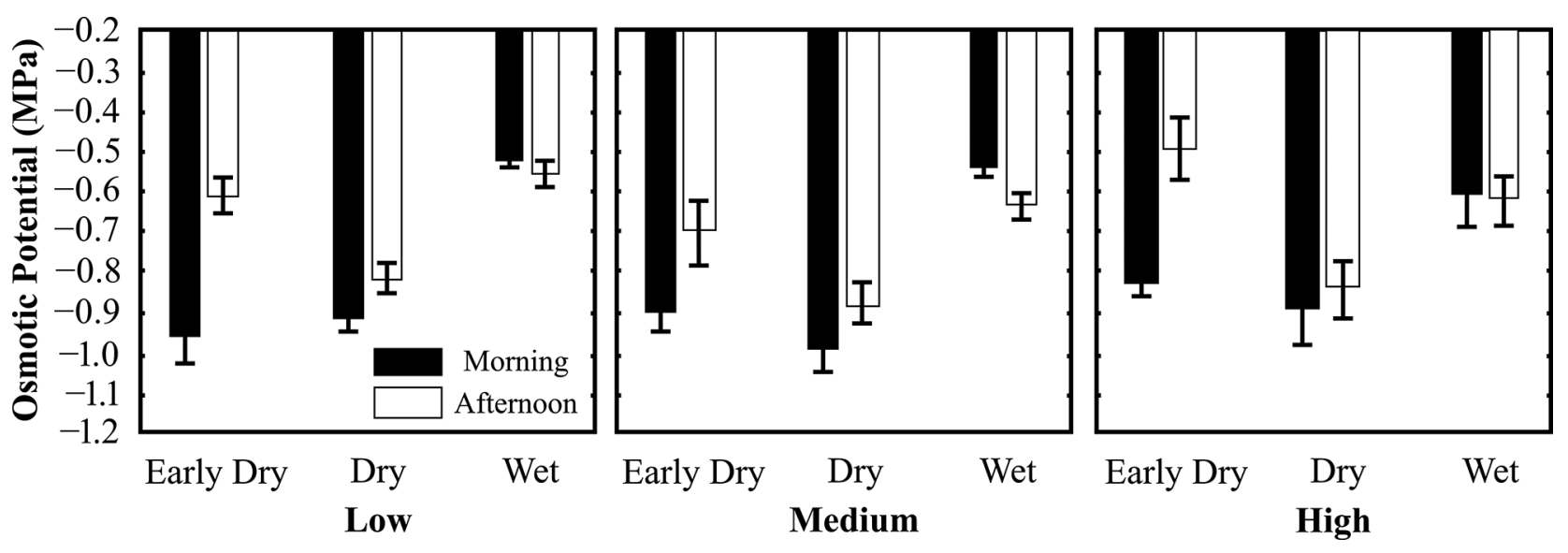

Fig. 3 Osmotic potentials of leaves of Tillandsia brachycaulos at two times of the day in three seasons and from different canopy strata in the dry deciduous tropical forest of Dzibilchaltún National Park. Data are means \pm standard errors $(n=5)$. 
Table 3

Osmotic Potential $\left(\Psi_{\pi}\right)$ and Water Potential $\left(\Psi_{w}\right)$ for Leaves of Tillandsia brachycaulos at Three Sampling Times during the Day for Data of all Seasons in the Tropical Dry Deciduous Forest in Dzibilchaltún National Park

\begin{tabular}{lccc}
\hline & Morning $(\mathrm{MPa})$ & Midday $(\mathrm{MPa})$ & Afternoon $(\mathrm{MPa})$ \\
\hline Osmotic potential & $-.79 \pm .03 *$ & $-.74 \pm .02$ & $-.68 \pm .02$ \\
Water potential & $-.68 \pm .03$ & $-.66 \pm .03$ & $-.65 \pm .04$ \\
\hline
\end{tabular}

Note. Data are means \pm standard errors $(n=45)$.

* Significantly different (Tukey, $P<0.05$ ).

\section{Tissue Water Relations}

Osmotic potential changed during the year for leaf tissues of T. brachycaulos ( $\Psi$; fig. 3 ). Values of $\Psi_{\pi}$ were lower in the morning compared with the midday and afternoon, independent of the season $(P<0.05$; table 3$)$. During the early dry and dry seasons, morning $\Psi_{\pi}$ values were lower than during the wet season (fig. 3). Combined $\Psi_{\pi}$ values for all strata were lowest in the dry season, higher in the early dry season, and highest in the wet season $\left(F_{2,42}=4.05, P<0.05\right.$; fig. 4).

In the early dry and wet seasons, leaf relative capacitance was significantly different between the low and middle strata (fig. 5 for the early dry season only; $P<0.05$ ). In the wet season, epiphytes in the high stratum had a high variation in leaf relative capacitance, and no differences in leaf relative capacitance occurred among strata in the dry season (fig. 6).

The volumetric elastic modulus of the leaf samples varied over a range of $4.3 \mathrm{MPa}$, with the lowest value occurring for leaves in the high stratum during the dry season, indicating a relatively higher cell wall elasticity (table 4 ). The highest value for $\epsilon$ occurred for leaves in the middle stratum during the wet season. Leaves in the wet season, combined for all strata, had a greater $\epsilon$ than those in either of the other seasons, significantly so for the early dry season $(P=0.02)$ and for the combined early and dry seasons $(P=0.003)$.

\section{Discussion}

\section{Light Microenvironment}

During the dry season, individuals of Tillandsia brachycaulos received eight times more daily PPF than the same individuals in the wet season. Such an extreme change in the light environment belies the abundance of T. brachycaulos in all strata, covering the stems and canopy of the dry forest trees in the Yucatán

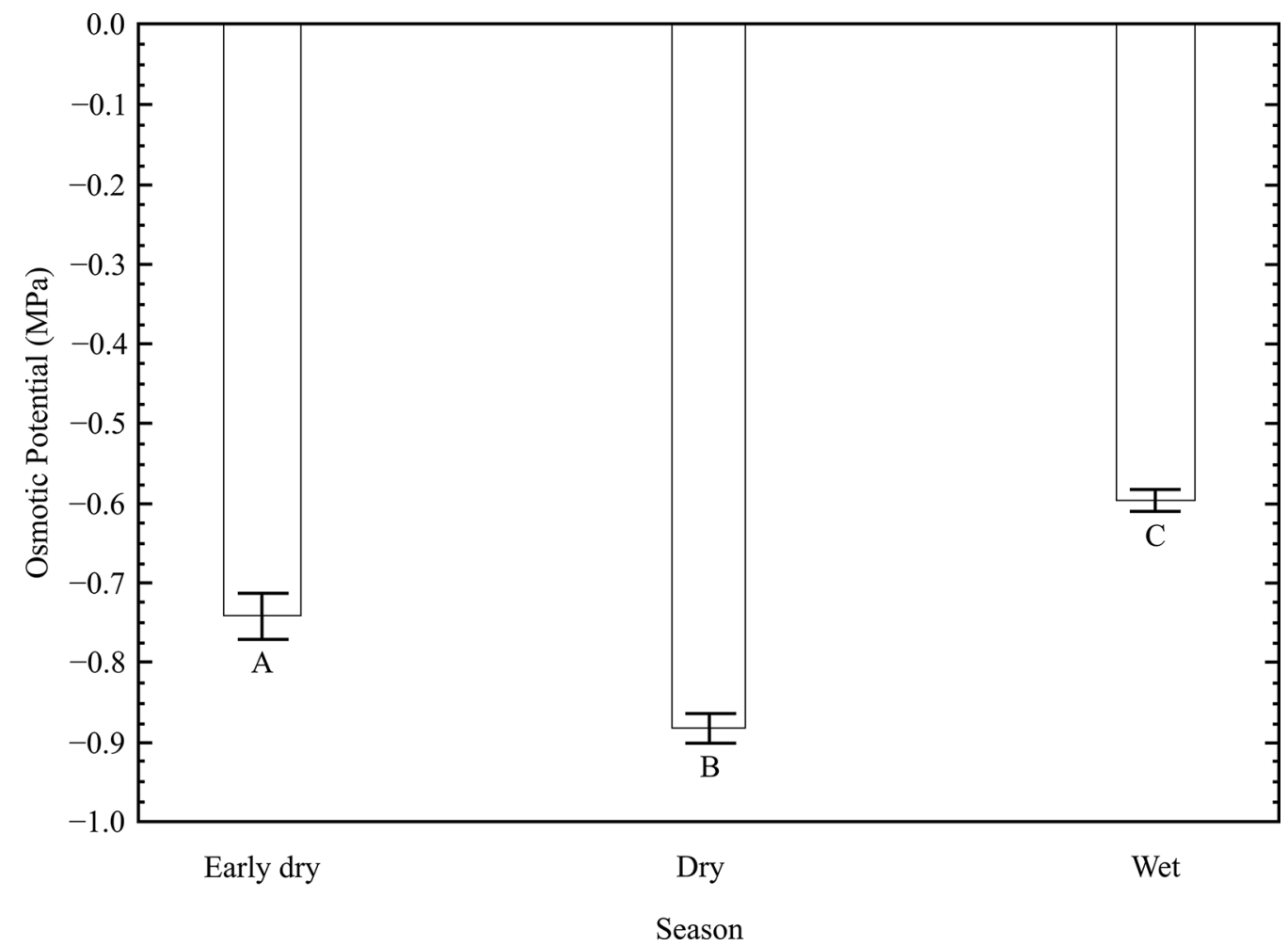

Fig. 4 Osmotic potentials of leaves of Tillandsia brachycaulos in the dry deciduous tropical forest of Dzibilchaltún National Park in three seasons. Data are means \pm standard errors $(n=45)$. Different letters indicate significant differences (Tukey, $P<0.05)$. 


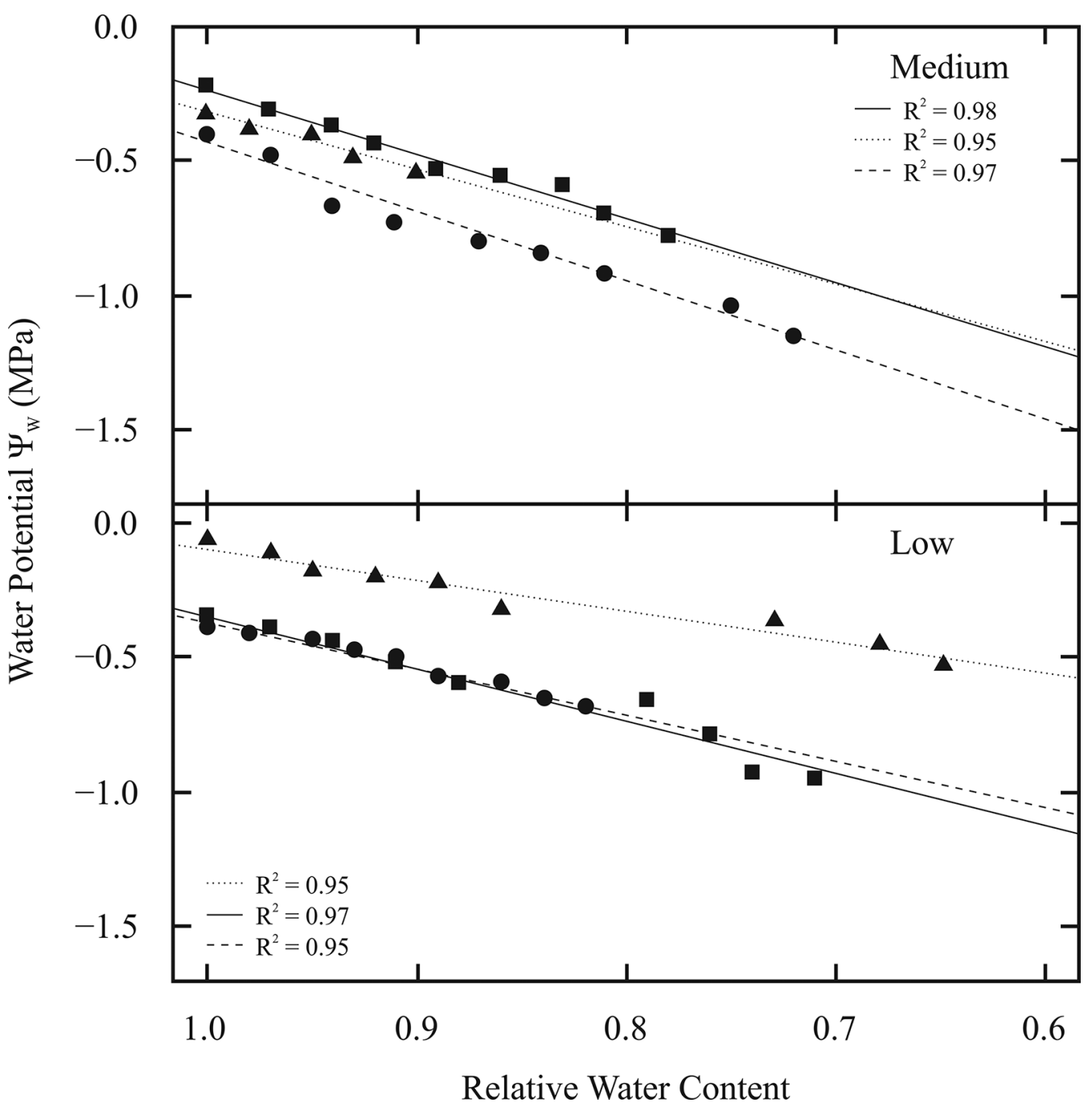

Fig. 5 Water potential isotherms in the early dry season for leaf tissues of Tillandsia brachycaulos from plants from the low and medium strata. Different symbols indicate measurements of different individuals.

Peninsula. The ability to acclimate to such a large change in PPF indicates a high photosynthetic plasticity for T. brachycaulos and has been observed in several other studies (Graham and Andrade 2004; Cervantes et al. 2005; González-Salvatierra et al. 2010; Cach-Pérez et al. 2018).

\section{Leaf Temperatures}

The midday leaf temperatures of $T$. brachycaulos were higher than the air temperature during the early dry and dry seasons, a result of their nocturnal stomatal opening associated with CAM. This increase in the leaf temperature of plants in the lower canopy has been correlated with reduced flowering and growth for T. brachycaulos (Cervantes et al. 2005). Midday leaf temperatures were lower than the air temperature for the middle and lower strata during the wet season, most likely due to latent heat loss because of daytime transpiration in well-watered plants of T. brachycaulos (Graham and Andrade 2004). Midday leaf temperatures were higher than the air temperature in the wet season for individuals in the upper strata, indicating that water stress during the wet season may still occur for this location in the canopy.

Predawn leaf temperatures that are lower than the air temperature indicate the possibility of dew deposition, a source of water with high water potential (Nobel 2009). This can occur even in the dry season, when most trees are leafless and epiphytes are exposed to a clear, cold sky at night (Andrade 2003; ChávezSahagún et al. 2019). Dew and fog events are positively correlated with vascular epiphyte densities and survival during the dry season and are related to epiphyte position in tropical dry forests (Andrade 2003; Graham and Andrade 2004; ReyesGarcía et al. 2008, 2012; de la Rosa-Manzano et al. 2014a; Wu et al. 2018; Chávez-Sahagún et al. 2019).

\section{Plant Water Relations}

Leaf osmotic potential was significantly lower in the morning than in the evenings, indicating organic acid production during 


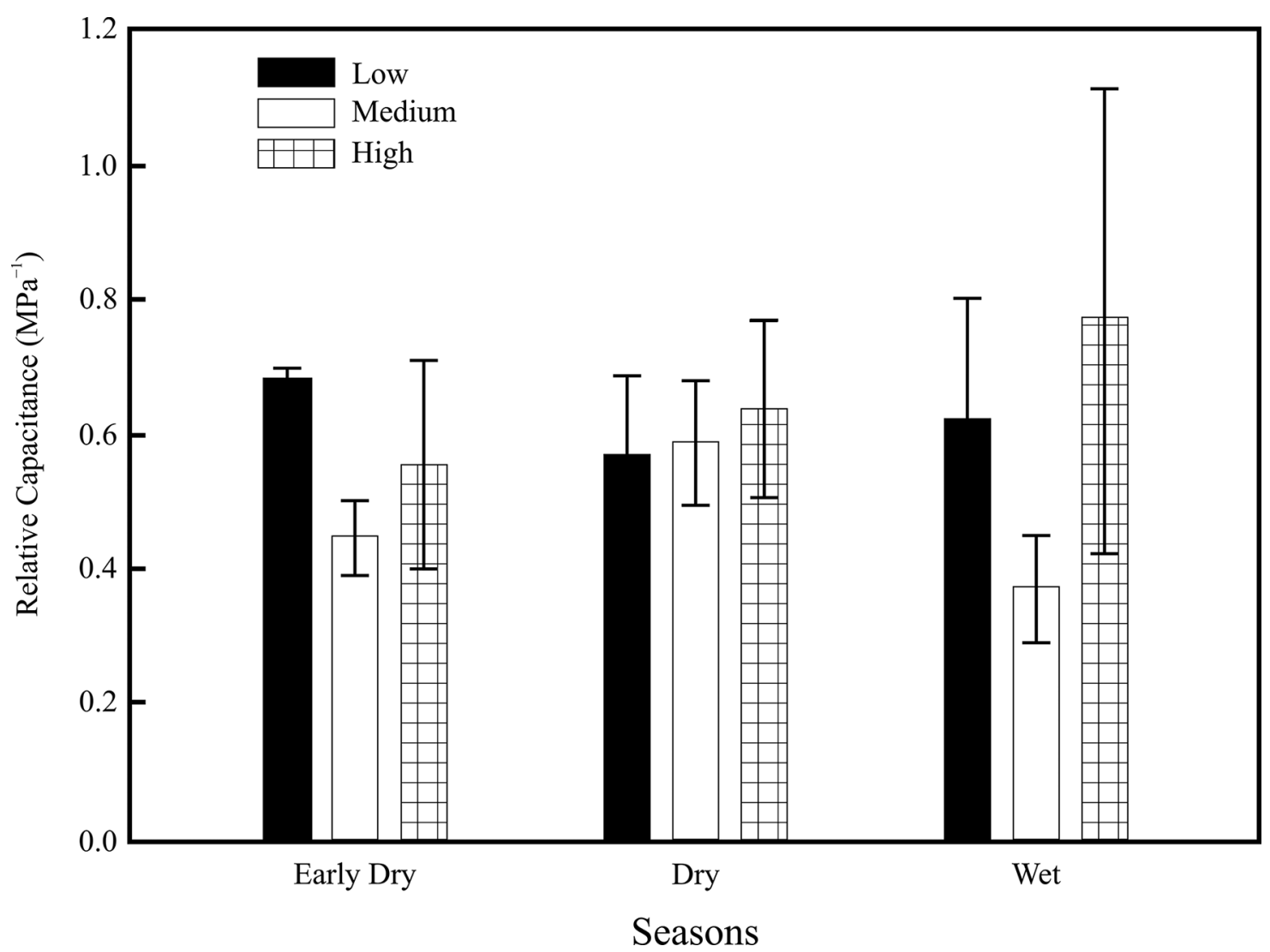

Fig. 6 Relative capacitance of leaves of Tillandsia brachycaulos in three different microhabitats and in three seasons in the dry deciduous tropical forest of Dzibilchaltún National Park. Data are means \pm standard errors $(n=3)$.

CAM; the values reported here are similar to those for other epiphytes (Zotz and Hietz 2001; Martin et al. 2004; Cach-Pérez et al. 2018). The relatively low $\Psi_{\pi}$ values in the early dry season could be associated with the significantly lower relative capacitance in the middle stratum compared with the low stratum during this time. Indeed, the low relative capacitance of $T$. brachycaulos in the middle stratum could indicate relatively suitable conditions for establishment and growth (Mondragón et al. 2004; Cervantes et al. 2005; Reyes-García et al. 2008; de la Rosa-Manzano et al. 2014a), as in other tropical forests (Johansson 1974; Ter Steege and Cornelissen 1989; Nieder et al. 2000).

Osmotic adjustments in epiphytic bromeliads between seasons do not tend to be substantial (Martin et al. 2004), in agreement with our results. A relatively low average leaf $\epsilon$ and a high relative capacitance for these plants indicate that water storage capacity may be more important than maintenance of high turgor by means of rigid cell walls and low osmotic potentials (Nowak and Martin 1997). Indeed, when water from rain, dew, or fog is available for these epiphytes, it is at near-zero water potential, and thus low tissue osmotic potentials may not be necessary for water uptake as they might be for plants with roots in a drying soil.

In the combined early dry and dry seasons, T. brachycaulos had significantly lower $\epsilon$ than during the wet season, indicating that maintenance of turgor by decreasing cell wall elasticity and $\Psi_{\pi}$ occurred more under drying conditions. Although we did not examine the water relations among different leaf tissues, other studies have indicated that preferential loss of water from the hydrenchyma is the result of differences in both osmotic potentials and cell wall elasticities (Nowak and Martin 1997).

Table 4

Volumetric Elastic Modulus ( $\epsilon$ ) for Leaves of Tillandsia brachycaulos at Three Locations in the Canopy in Three Seasons in the Tropical Dry Deciduous Forest in Dzibilchaltún National Park

\begin{tabular}{lccr}
\hline Stratum & Early dry $(\mathrm{MPa})$ & Dry $(\mathrm{MPa})$ & Wet $(\mathrm{MPa})$ \\
\hline Low & $1.18 \pm .27$ & $2.74 \pm .72$ & $2.96 \pm 1.45$ \\
Middle & $2.68 \pm .11$ & $2.08 \pm .58$ & $5.32 \pm 1.01$ \\
High & $1.43 \pm .06$ & $.98 \pm .36$ & $3.12 \pm .45$ \\
\hline
\end{tabular}

Note. Data are means \pm standard errors $(n=3)$. 


\section{Conclusions}

Our data indicate that the leaf relative capacitance of plants of Tillandsia brachycaulos from the middle stratum increased in the dry season but that individuals in all strata maintained high relative capacitance during the year. Osmotic and cell wall elasticity adjustments were modest for this epiphytic species, even though it is exposed to dramatic changes in microenvironment. Such responses are in agreement with the observation that when water is available, it is of high water potential, and thus water storage is the main strategy for surviving in such extreme conditions for this species. Midday high leaf temperatures of $T$. brachycaulos in some microsites indicate low convective heat dissipation without major consequences for its tissue water relations. Further studies with $T$. brachycaulos in common gardens and the laboratory will be necessary for examining its responses to even greater microenvironment variability under climate change conditions.

\section{Acknowledgments}

We thank three anonymous reviewers who provided substantial comments on an earlier version of the manuscript. This study was supported by a small grant for undergraduate research (SNI-estudiantes 105092) by Consejo Nacional de Ciencia y Tecnología, Mexico.

\section{Literature Cited}

Andrade JL 2003 Dew deposition on epiphytic bromeliad leaves: an important event in a Mexican tropical dry deciduous forest. J Trop Ecol 19:479-488.

Andrade JL, JC Cervera, EA Graham 2009 Microenvironments, water relations, and productivity of CAM plants. Pages 95-120 in E de la Barrera, WK Smith, eds. Perspectives in biophysical plant ecophysiology: a tribute to Park S. Nobel. Universidad Nacional Autónoma de México, Mexico City.

Andrade JL, PS Nobel 1997 Microhabitats and water relations of epiphytic cacti and ferns in a lowland Neotropical forest. Biotropica 29:261-270.

Benzing DH 1990 Vascular epiphytes, general ecology and related biota. Cambridge University Press, New York.

2000 Bromeliaceae: profile of an adaptive radiation. Cambridge University Press, Cambridge.

Cach-Pérez MJ 2013 Bromeliáceas epifitas de la península de Yucatán como indicadoras de los posibles efectos del cambio climático regional. PhD diss. Centro de Investigación Científica de Yucatán, A.C., Mérida, Mexico.

Cach-Pérez MJ, JL Andrade, N Chilpa-Galván, M Tamayo-Chim, R Orellana, C Reyes-García 2013 Climatic and structural factors influencing epiphytic bromeliad community assemblage along a gradient of water-limited environments in the Yucatan Peninsula, Mexico. Trop Conserv Sci 6:283-302.

Cach-Pérez MJ, JL Andrade, C Reyes-García 2018 Morphophysiological plasticity in epiphytic bromeliads across a precipitation gradient in the Yucatan peninsula, Mexico. Trop Conserv Sci 11:1-10.

Cervantes SE, EA Graham, JL Andrade 2005 Light microhabitats, growth and photosynthesis of an epiphytic bromeliad in a tropical dry forest. Plant Ecol 179:107-118.

Cervera JC, JL Andrade, JL Simá, EA Graham 2006 Microhabitats, germination, and establishment for Mammillaria gaumeri (Cactaceae), a rare species from Yucatan. Int J Plant Sci 167:311-319.

Chávez-Sahagún E, JL Andrade, G Zotz, C Reyes-García 2019 Dew can prolong photosynthesis and water status during drought in some epiphytic bromeliads from a seasonally dry tropical forest. Trop Conserv Sci 12:1-11.

Chilpa-Galván N, M Tamayo-Chim, JL Andrade, C Reyes-García 2013 Water table depth may influence the asymmetric arrangement of epiphytic bromeliads in a tropical dry forest. Plant Ecol 214:1037-1048.

Crain BJ, RL Tremblay 2017 Hot and bothered: changes in microclimate alter chlorophyll fluorescence measures and increase stress levels in tropical epiphytic orchids. Int J Plant Sci 178:503-511.

de la Rosa-Manzano E, JL Andrade, G Zotz, C Reyes-García 2014a Epiphytic orchids in tropical dry forest of Yucatan, Mexico: species occurrence abundance and correlations with host tree characteristics and environmental conditions. Flora 209:100-109.
$2014 b$ Physiological responses to drought of five epiphytic orchid species from two tropical dry forests of the Yucatan Peninsula. Bot Sci 92:607-616.

2017 Physiological plasticity of epiphytic orchids from two contrasting tropical dry forests. Acta Oecol 85:25-32.

González-Salvatierra C, JL Andrade, F Escalante-Erosa, K García-Sosa, LM Peña-Rodríguez 2010 Antioxidant content in two CAM bromeliad species as a response to seasonal light changes in a tropical dry forest. J Plant Physiol 167:792-799.

Graham E, JL Andrade 2004 Drought tolerance associated with vertical stratification of two co-ocurring epiphytic bromeliads in a tropical dry forest. Am J Bot 91:699-706.

Griffiths H, K Maxwell 1999 In memory of C. S. Pittendrigh: does exposure in forest canopies relate to photoprotective strategies in epiphytic bromeliads? Funct Ecol 13:15-23.

Griffiths H, JAC Smith 1983 Photosynthetic pathways in the Bromeliaceae of Trinidad: relations between life-forms, habitat preference and the occurrence of CAM. Oecologia 60:176-184.

Hietz P, O Briones 1998 Correlation between water relations and within-canopy distribution of epiphytic ferns in a Mexican cloud forest. Oecologia 114:305-316.

Johansson D 1974 Ecology of vascular epiphytes in West African rain forest. Acta Phytogeogr Suec 59:1-129.

Jones HG 2013 Plants and microclimate: a quantitative approach to environmental plant physiology. Cambridge University Press, Cambridge.

Martin CE 1994 Physiological ecology of the Bromeliaceae. Bot Rev 60:1-82.

Martin CE, TC Lin, KC Lin, CC Hsu, WL Chiou 2004 Causes and consequences of high osmotic potentials in epiphytic higher plants. J Plant Physiol 161:1119-1124.

Maxwell C, H Griffiths, AM Borland, AJ Young, MSJ Broadmeadow, MC Fordham 1995 Short-term photosynthetic responses of the C3CAM epiphyte Guzmania monostachia var. monostachia to tropical seasonal transitions under field conditions. Funct Plant Biol 22:771781.

Mondragón D, LM Calvo-Irabien, DH Benzing 2004 The basis for obligate epiphytism in Tillandsia brachycaulos (Bromeliaceae) in a Mexican tropical dry forest. J Trop Ecol 20:97-104.

Mondragón D, R Durán, I Ramírez, I Olmsted 1999 Population dynamics of Tillandsia brachycaulos Schltdl. (Bromeliaceae) in Dzibilchaltun National Park, Yucatán. Selbyana 20:250-255.

Nieder J, S Engwald, M Klauwun, W Barthlott 2000 Spatial distribution of vascular epiphytes (including hemiepiphytes) in a lowland Amazonian rain forest (Surumoni crane plot) of southern Venezuela. Biotropica 32:385-396.

Nobel PS 2009 Physicochemical and environmental plant physiology. Academic Press, San Diego, CA. 
Nowak EJ, CE Martin 1997 Physiological and anatomical responses to water deficits in the CAM epiphyte Tillandsia ionantha (Bromeliaceae). Int J Plant Sci 158:818-826.

Ogburn RM, EJ Edwards 2012 Quantifying succulence: a rapid, physiologically meaningful metric of plant water storage. Plant Cell Environ 35:1533-1542.

Orellana R 1999 Evaluación climática. Pages 163-182 in A García, J Córdova, eds. Atlas de procesos territoriales de Yucatán. Facultad de Arquitectura, Universidad Autónoma de Yucatán, Mérida, México.

Orellana R, C Espadas, C Conde, C Gay 2009 Atlas: escenarios de cambio climático en la Península de Yucatán. Centro de Investigación Científica de Yucatán, A.C., Mérida, Mexico.

Petter G, K Wagner, W Wanek, EJ Sánchez-Delgado, G Zotz, J Sarmento-Cabral, J Kreft 2016 Functional leaf traits of vascular epiphytes: vertical trends within the forest, intra- and interspecific trait variability, and taxonomic signals. Funct Ecol 30:188-198.

Rascher U, M Freiberg, U Lüttge 2012 Functional diversity of photosynthetic light use of 16 vascular epiphyte species under fluctuating irradiance in the canopy of a giant Virola michelii (Myristicaceae) tree in the tropical lowland forest of French Guyana. Front Plant Sci 2:1-12.

Reyes-García C, H Griffiths, E Rincón, P Huante 2008 Niche differentiation in tank and atmospheric epiphytic bromeliads of a seasonally dry forest. Biotropica 40:168-175.

Reyes-García C, M Mejia-Chang, H Griffiths 2012 High but not dry: diverse epiphytic bromeliad adaptations to exposure within a seasonally dry tropical forest community. New Phytol 193:745-754.

Ricalde MF, JL Andrade, R Durán, JM Dupuy, JL Simá, R UsSantamaría, LS Santiago 2010 Environmental regulation of carbon isotope composition and crassulacean acid metabolism in three plant communities along a water availability gradient. Oecologia 164:871-880.

Sinclair R 1983 Water relations of tropical epiphytes. II. Performance during droughting. J Exp Bot 34:1664-1675.

Smith JAC, H Griffiths, U Lüttge, CE Crook, NM Griffiths, KH Stimmel 1986 Comparative ecophysiology of CAM and C3 bromeliads. IV. Plant water relations. Plant Cell Environ 9:395-410.

Ter Steege H, JHC Cornelissen 1989 Distribution and ecology of vascular epiphytes in lowland rain forest of Guyana. Biotropica 21:331-339.

Thien LB, AS Bradburn, AL Welden 1982 The woody vegetation of Dzibilchaltún, a Maya archaeological site in northwest Yucatan, Mexico. Middle American Research Institute, Tulane University, New Orleans.

Wagner K, W Bogusch, G Zotz 2013 The role of the regeneration niche for the vertical stratification of vascular epiphytes. J Trop Ecol 29:277-290.

Wu Y, L Song, W Liu, W Liu, S Li, P Fu, Y Shen, et al 2018 Fog water is important in maintaining the water budgets of vascular epiphytes in an Asian tropical karst forests during the dry season. Forests 9:260.

Zhang W, H Hu, SB Zhang 2016 Divergent adaptive strategies by two co-occurring epiphytic orchids to water stress: escape or avoidance? Front Plant Sci 7:588.

Zotz G 2016 Plants on plants: the biology of vascular epiphytes. Springer, Berlin.

Zotz G, JL Andrade 1998 Water relations of two co-occurring epiphytic bromeliads. J Plant Physiol 152:545-554.

Zotz G, P Hietz 2001 The physiological ecology of vascular epiphytes: current knowledge, open questions. J Exp Bot 52:2067-2078. 